\title{
Rapid sea level rise in the aftermath of a Neoproterozoic snowball Earth
}

\author{
P. M. Myrow, ${ }^{1 *}$ M. P. Lamb, ${ }^{2}$ R. C. Ewing ${ }^{3}$ \\ ${ }^{1}$ Department of Geology, Colorado College, Colorado Springs, C0 80903, USA. ²Division of Geological and Planetary Sciences, California Institute of Technology, Pasadena, \\ CA 91124, USA. ${ }^{3}$ Department of Geology and Geophysics, Texas A\&M University, College Station, TX 77843, USA. \\ ${ }^{*}$ Corresponding author. Email: pmyrow@coloradocollege.edu
}

Earth's most severe climate changes occurred during global-scale snowball-Earth glaciations, which profoundly altered Earth's atmosphere, oceans, and biosphere. Extreme rates of glacio-eustatic sea-level rise are a fundamental prediction of the snowball Earth hypothesis, but supporting geologic evidence is lacking. We use paleohydraulic analysis of wave ripples and tidal laminae of the Elatina Formation, Australia - deposited following the Marinoan glaciation ca. 635Ma - to show that water depths of 9-16m remained nearly constant for $\sim 100 y$ rs throughout $27 \mathrm{~m}$ of sediment accumulation. This accumulation rate was too great to have been accommodated by subsidence, and instead indicates an extraordinarily rapid rate of sea-level rise $(0.2-0.27 \mathrm{~m} / \mathrm{yr})$. Our results substantiate a fundamental prediction of snowball Earth models of rapid deglaciation during the early transition to a super-greenhouse climate.

Close monitoring of the Antarctic ice sheet indicates rapid and significant collapse (1) due in part to anthropogenically induced climate change. Present rates of ice sheet collapse are constrained by observations, but little is known about rates for ancient glaciations. The Late Neoproterozoic snowball Earth events represent an extreme climate change scenario, in which the collapse of global ice sheets during deglaciation are thought to have caused extremely large and rapid sea-level rise (2-4). Complete deglaciation occurring over only $2-10 \mathrm{kyr}$ and rapid sea-level rise is inferred from estimates of ice volume and greenhouse conditions (5) with $\mathrm{CO}_{2}$ of $\sim 400-660$ times present atmospheric levels and surface temperatures of $\sim 50^{\circ} \mathrm{C}(2)$. However, paleomagnetic reversals within cap carbonate beds, which mantle glaciogenic deposits and are part of the glacio-eustatic sealevel rise succession (Fig. 1A), indicate slow deposition over $>10^{4}$ to $10^{6}$ yrs $(6,7)$, presenting a major obstacle to the snowball Earth hypothesis. Although slow rise rates may be tied to late-stage thermal expansion of oceans, rather than ice melt (4), geologic evidence of rapid sea-level rise during deglaciation is lacking. Here we show that a siltstone unit that rests below a cap carbonate records the extremely rapid initial sea level rise predicted by the snowball Earth hypothesis.

The Elatina Formation in South Australia contains a unique record of the Marinoan ( 635Ma) snowball Earth that includes evidence for ice advance and subsequent deglaciation, including the early postglacial interval, as it is directly overlain by the Nuccaleena cap carbonate ( 8 ) (Fig. 1A). Paleomagnetic data constrain deposition of the formation to $<15^{\circ}$ north latitude (9), supporting a low-latitude glaciation consistent with a snowball Earth. Within the deglaciation succession, a $\sim 30 \mathrm{~m}$ thick, tidal-rhythmite siltstone unit records a complete daily record of sedimentation driven by tidal currents and wave action (10). We use a suite of sedimentary structures in these deposits to test a fundamental prediction of the snowball Earth model, namely, rapid glacio-eustatic rise during deglaciation.

Siltstone of the upper Elatina Formation crops out across $\sim 4500 \mathrm{~km}^{2}$ of the Adelaide Rift Complex (ARC) and Stuart Shelf of South Australia. It consists of cm-scale packages of $\sim 12$ pairs of mm-thick silt and muddy silt laminae (average grainsizes are 61 and $37 \mu \mathrm{m}$, respectively; 11 ) that vertically thicken and thin. These lamina pairs were initially considered to be varves formed in a periglacial lake (12), and later to be tidal delta deposits formed by spring-neap cycles (13). The rhythmites are preserved within bedforms (e.g., ripples) that aggrade vertically with few erosional surfaces, and individual bedforms can be continuously tracked vertically across meters of strata (8). Within this facies, several hierarchies of bedforms are preserved.

First-order (i.e., the largest class) bedforms are straightcrested, relatively symmetrical ripples (Fig. 1, B and C) with average heights of $h=1.8 \pm 0.6 \mathrm{~cm}(1 \sigma)$, and average crest-tocrest spacings of $\lambda=33 \pm 11 \mathrm{~cm}$ (table S1). Locally, cross-lamination shows evidence of convex-up lamination (Fig. 2A), typical of combined-flow ripples (14), and gradual vertical shifts, including reversals, in migration direction (Fig. 2C). Several new observations provide independent evidence that the large ripples were deposited under reversing tidal currents. First, large ripple strata locally contain reactivation 
surfaces, which indicate a current reversal that eroded the bedform flank. Second, ripple cross-laminated beds contain isolated, fully preserved ripples, less than $5 \mathrm{~mm}$ in height, that rest just below, or on, the larger ripple crests (Fig. 2B). These small ripples are oriented opposite to the dominant ripple cross-lamination and are bounded by the thickest laminae of the tidal bundles, indicating that the strongest reversing currents (i.e., spring tides) produced traction transport against the dominant tide. Finally, in cases, the first-order ripple cross-lamination contains two alternating types of erosional surfaces, half of which dip antithetical to the main cross-lamination and truncate the ripple foresets, whereas the others dip in the dip direction of the large ripples, but at a lower angle (Fig. 2D). The two truncation-surface types alternate upwards along the trace of the preserved climbing ripple crests, and the surfaces are contiguous with mm-thick white laminae that define rhythmite bundle boundaries, which again links the erosion surfaces to spring tides and cyclic lamination to reversing tidal currents.

The troughs of the first-order ripples preserve vertically aggraded second-order bedforms (i.e., smaller bedforms superimposed on the first-order bedforms) that align perpendicular to the first-order ripple crests (Fig. 1B). The secondorder bedforms consist of symmetrical to moderately asymmetrical 2D ripples with $h=0.4 \pm 0.2 \mathrm{~cm}$ and $\lambda=6.0 \pm 2.1 \mathrm{~cm}$ (table S1). Second-order bedforms show locally developed bifurcations typical of straight-crested wave ripples. Their aspect ratio is $h / \lambda=0.06 \pm 0.02$, and the ripple symmetry index (RSI), which is the ratio of the width of the stoss-to-lee sides, is $1.9 \pm 1.6$ (table S2), making them consistent with post-vortex anorbital wave ripples (15). Aspect ratios of these bedforms are smaller than wave ripples produced experimentally in sand but are consistent with ripples formed in silty sand beds in the presence of significant suspension of mud (16).

The sedimentological characteristics indicate deposition during both wave and current activity in an ice-free body of water, consistent with the latest- to post-snowball Earth climate. Whereas there is some spatial and stratigraphic variation, the most complete succession shows no systematic vertical changes in the heights and spacings of first or second order ripples throughout at least $16 \mathrm{~m}$ of the rhythmite unit (8). The small ripples are oriented NNE-SSW (fig. S1 and table S3), orthogonal to the first-order tidally influenced ripples, and thus wave action that generated the second-order ripples was normal to the tidal currents, consistent with expected equatorial easterlies and NW oriented wind fields inferred from eolian dunes (17).

Wave ripples in sand and silt, whether orbital or anorbital, show a consistent relation between their aspect ratio, $h / \lambda$, and the formative wave orbital diameter, $d_{\mathrm{o}}$ (Fig. 3A), which can be used to reconstruct the paleo-water depth. For the Elatina wave ripples, we estimate $d_{0}=0.95 \pm 0.15 \mathrm{~m}(11)$.
Wave generation constraints (11) dictate that for a given average wind speed and $d_{0}=0.95 \pm 0.15 \mathrm{~m}$, water depths varied by less than $\sim 7 \mathrm{~m}$ (Fig. 3B). A near uniform average daily wind speed is expected due to trade winds, possibly modulated by diurnal katabatic winds (8). A larger change in water depth during deposition requires an unlikely systematic co-variation between depth and wind speed (Fig. 3B), and therefore relative sea level must have risen nearly commensurate with sediment accumulation.

Constraints on absolute water depth require an estimate of the wave period or average wind speed during ripple formation. Oscillatory duct experiments (16) with $d_{0}=0.8-1.0 \mathrm{~m}$ in silty sand produced ripples of equivalent dimensions to the Elatina with wave periods of $T=5.5-7.5 \mathrm{~s}$. The wave generation model (11) indicates that this combination of wave parameters $\left(T=5.5-7.5 \mathrm{~s}\right.$ and $\left.d_{\mathrm{o}}=0.8-1.1 \mathrm{~m}\right)$ limits absolute water depths to $9-30 \mathrm{~m}$ (Fig. 3B and fig. S2). The deeper end member $(30 \mathrm{~m})$ requires the unlikely case of reoccurring whole-gale force $(25 \mathrm{~m} / \mathrm{s})$ winds, whereas the lower-bound (9$16 \mathrm{~m}$ ) indicates reasonable average wind speeds of $\sim 16 \mathrm{~m} / \mathrm{s}$, equivalent to speeds previously proposed (8). Burial of the Elatina Formation would have been to $\sim 5-6 \mathrm{~km}$ depth (18) with compaction of $\sim 40 \%$ (19). Thus, the original (decompacted) deposit thickness of $\sim 27 \mathrm{~m}$ (11) exceeds our estimated maximum change in water depth $(\sim 7 \mathrm{~m})$, in addition to the likely absolute water depth (9-16 m; Fig. 3B), which provides two independent constraints that the rate of relative sea-level rise must have closely matched the accumulation rate.

The preservation of tidal laminae in the Elatina Formation provides a means to explain how two scales of superimposed bedforms accrete over $27 \mathrm{~m}$ with little change in ripple dimensions and inferred water depth. Williams (13) identified 1,580 neap-spring tidal cycles in a $9.39 \mathrm{~m}$ thick core of the Elatina Formation devoid of truncation surfaces, which he used to constrain depositional time, but did not consider implications for sea-level rise. Alternating thick and thin packages of laminae throughout the core, with each package containing 12 pairs of silt and mud laminae, represent the neap-spring cycles within half a lunar month. Spectral analysis of these packages yielded the number of lunar months per year $(13.1 \pm 0.1)$, and $60.3 \pm 0.5 y$ rs for deposition of the $9.39 \mathrm{~m}$ thick core (13). The resulting accumulation rate is used to estimate that the decompacted original thickness of $\sim 27 \mathrm{~m}$ determined for our rippled section was deposited over $\sim 100 y$ rs with an accumulation rate of $\sim 27 \mathrm{~cm} / \mathrm{yr}$ (11), or $20 \mathrm{~cm} / \mathrm{yr}$ if water depth shallowed during deposition by the maximum allowed $(7 \mathrm{~m})$. This accumulation rate is higher than any previously estimated for a large marine basin over century timescales or longer (20), consistent with high suspended-sediment concentrations during rapid deglaciation of a snowball Earth episode. Given that subsidence over 100 
years would be negligible (21), the inferred $\sim 27 \mathrm{~m}$ of accumulation could only be accomplished through rapid rise of sea level, specifically at $20-27 \mathrm{~cm} / \mathrm{yr}$.

The rhythmite unit represents a fraction of the total deglaciation deposit, and duration estimates for complete deglaciation, based on ice volumes and greenhouse conditions, are typically $2-10 \mathrm{kyr}$ (6kyr average) (5). The total sea-level rise due to melting of Marinoan glaciers has been estimated at $~ 1,000-1,500 \mathrm{~m}(2,22)$, which likely varied spatially due to gravitational effects (23). A glacioeustatic rise of $1.5 \mathrm{~km}$ over $2-10 \mathrm{kyr}$ corresponds to a long-term rise rate of $15-75 \mathrm{~cm} / \mathrm{yr}$, or $25 \mathrm{~cm} / \mathrm{yr}$ for a 6 -kyr deglaciation, which is consistent with our independent short-term geologic constraint of 20$27 \mathrm{~cm} / \mathrm{yr}$. This rate of sea-level rise is one-hundred-fold greater than present-day rates (24) and five times greater than the highest during Pleistocene deglaciations (25). Sealevel rise of this magnitude is a strong confirmation of a major tenet of the snowball Earth hypothesis, namely rapid deglaciation during the early transition from icehouse to hypergreenhouse conditions.

\section{REFERENCES AND NOTES}

1. H. D. Pritchard, S. R. M. Ligtenberg, H. A. Fricker, D. G. Vaughan, M. R. van den Broeke, L. Padman, Antarctic ice-sheet loss driven by basal melting of ice shelves. Nature 484, 502-505 (2012). doi:10.1038/nature10968 Medline

2. P. F. Hoffman, D. S. Abbot, Y. Ashkenazy, D. I. Benn, J. J. Brocks, P. A. Cohen, G. M. Cox, J. R. Creveling, Y. Donnadieu, D. H. Erwin, I. J. Fairchild, D. Ferreira, J. C. Goodman, G. P. Halverson, M. F. Jansen, G. Le Hir, G. D. Love, F. A. Macdonald, A. C. Maloof, C. A. Partin, G. Ramstein, B. E. J. Rose, C. V. Rose, P. M. Sadler, E. Tziperman, A. Voigt, S. G. Warren, Snowball Earth climate dynamics and Cryogenian geology-geobiology. Sci. Adv. 3, e1600983 (2017). doi:10.1126/sciadv.1600983 Medline

3. J. L. Kirschvink, "Late Proterozoic low-latitude glaciation: The snowball Earth," in The Proterozoic Biosphere, J. W. Schopf and C. Klein, Eds. (Cambridge Univ. Press, 1992); pp. 51-52.

4. J. Yang, M. F. Jansen, F. A. Macdonald, D. S. Abbot, Persistence of a freshwater surface ocean after a snowball Earth. Geology 45, 615-618 (2017). doi:10.1130/G38920.1

5. P. F. Hoffman, A. J. Kaufman, G. P. Halverson, D. P. Schrag, A Neoproterozoic snowball earth. Science 281, 1342-1346 (1998). doi:10.1126/science.281.5381.1342 Medline

6. R. I. F. Trindade, E. Font, M. S. D'Agrella-Filho, A. C. R. Nogueira, C. Riccomini, Lowlatitude and multiple geomagnetic reversals in the Neoproterozoic Puga cap carbonate, Amazon craton. Terra Nova 15, 441-446 (2003). doi:10.1046/j.13653121.2003.00510.x

7. B. Kilner, C. Mac Niocaill, M. Brasier, Low-latitude glaciation in the Neoproterozoic of Oman. Geology 33, 413-416 (2005). doi:10.1130/G21227.1

8. C. V. Rose, A. C. Maloof, B. Schoene, R. C. Ewing, U. Linnemann, M. Hofmann, J. M. Cottle, The End-Cryogenian Glaciation of South Australia. Geosci. Can. 40, 256293 (2013). doi:10.12789/geocanj.2013.40.019

9. D. A. D. Evans, T. D. Raub, Neoproterozoic glacial palaeolatitudes: A global update. Geol. Soc. London Memoirs 36, 93-112 (2011).

10. W. V. Preiss, "Stratigraphic nomenclature and classification," in The Adelaide Geosyncline: Late Proterozoic Stratigraphy, Sedimentation, Palaeontology and Tectonics, W. V. Preiss, Ed. (Bulletin 53, Geological Survey of South Australia, 1987), pp. 29-34.

11. Materials and methods are available as supplementary materials.

12. G. E. Williams, Sunspot periods in the late Precambrian glacial climate and solarplanetary relations. Nature 291, 624-628 (1981). doi:10.1038/291624a0

13. G. E. Williams, Late Precambrian tidal rhythmites in South Australia and the history of the Earth's rotation. J. Geol. Soc. London 146, 97-111 (1989). doi:10.1144/gsigs.146.1.0097

14. P. M. Myrow, W. Fischer, J. W. Goodge, Wave-modified turbidites: Combined-flow shoreline and shelf deposits, Cambrian, Antarctica. J. Sediment. Res. 72, 641-656 (2002). doi:10.1306/022102720641

15. H. E. Clifton, J. R. Dingler, "Wave-formed structures and paleoenvironmental reconstruction," in Wave-Dominated Coastal Environments, B. Greenwood, R. A. Davis, Jr., Eds. (Elsevier, 1984) pp. 165-198.

16. M. P. Lamb, J. D. Parsons, High-density suspensions formed under waves. J. Sediment. Res. 75, 386-397 (2005). doi:10.2110/jsr.2005.030

17. G. E. Williams, Late Neoproterozoic periglacial aeolian sand sheet, Stuart Shelf, South Australia. Aust. J. Earth Sci. 45, 733-741 (1998). doi:10.1080/08120099808728429

18. P. W. Schmidt, G. E. Williams, The Neoproterozoic climatic paradox: Equatorial palaeolatitude for Marinoan glaciation near sea level in South Australia. Earth Planet. Sci. Lett. 134, 107-124 (1995). doi:10.1016/0012-821X(95)00106-M

19. J. P. Grotzinger, S. Gupta, M. C. Malin, D. M. Rubin, J. Schieber, K. Siebach, D. Y. Sumner, K. M. Stack, A. R. Vasavada, R. E. Arvidson, F. Calef 3rd, L. Edgar, W. F. Fischer, J. A. Grant, J. Griffes, L. C. Kah, M. P. Lamb, K. W. Lewis, N. Mangold, M. E. Minitti, M. Palucis, M. Rice, R. M. E. Williams, R. A. Yingst, D. Blake, D. Blaney, P. Conrad, J. Crisp, W. E. Dietrich, G. Dromart, K. S. Edgett, R. C. Ewing, R. Gellert, J. A. Hurowitz, G. Kocurek, P. Mahaffy, M. J. McBride, S. M. McLennan, M. Mischna, D. Ming, R. Milliken, H. Newsom, D. Oehler, T. J. Parker, D. Vaniman, R. C. Wiens, S. A. Wilson, Deposition, exhumation, and paleoclimate of an ancient lake deposit, Gale crater, Mars. Science 350, aac7575 (2015). doi:10.1126/science.aac7575 Medline

20. C. A. Partin, P. M. Sadler, Slow net sediment accumulation sets snowball Earth apart from all younger glacial episodes. Geology 44, 1019-1022 (2016). doi:10.1130/G38350.1

21. E. Carminati, G. Martinelli, Subsidence rates in the Po Plain, northern Italy: The relative impact of natural and anthropogenic causation. Eng. Geol. 66, 241-255 (2002). doi:10.1016/S0013-7952(02)00031-5

22. P. F. Hoffman, Strange bedfellows: Glacial diamictite and cap carbonate from the Marinoan (635 Ma) glaciation in Namibia. Sedimentology 58, 57-119 (2011). doi:10.1111/j.1365-3091.2010.01206.x

23. J. R. Creveling, J. X. Mitrovica, The sea-level fingerprint of a Snowball Earth deglaciation. Earth Planet. Sci. Lett. 399, 74-85 (2014). doi:10.1016/j.epsl.2014.04.029

24. T. M. Cronin, Rapid sea-level rise. Quat. Sci. Rev. 56, 11-30 (2012). doi:10.1016/i.quascirev.2012.08.021

25. T. Hanebuth, K. Stattegger, P. M. Grootes, Rapid flooding of the Sunda Shelf: A late-glacial sea-level record. Science 288, 1033-1035 (2000). doi:10.1126/science.288.5468.1033 Medline

26. R. C. Ewing, I. Eisenman, M. P. Lamb, L. Poppick, A. C. Maloof, W. W. Fischer, New constraints on equatorial temperatures during a Late Neoproterozoic snowball Earth glaciation. Earth Planet. Sci. Lett. 406, 110-122 (2014). doi:10.1016/j.epsl.2014.09.017

27. P. A. Allen, P. F. Hoffman, Extreme winds and waves in the aftermath of a Neoproterozoic glaciation. Nature 433, 123-127 (2005). doi:10.1038/nature03176 Medline

28. P. L. Wiberg, C. K. Harris, Ripple geometry in wave-dominated environments. J. Geophys. Res. Oceans 99, 775-789 (1994). doi:10.1029/93JC02726

29. Z. J. You, B. Yin, A unified criterion for initiation of sediment motion and inception of sheet flow under water waves. Sedimentology 53, 1181-1190 (2006). doi:10.1111/j.1365-3091.2006.00810.x

30. M. R. Johnson, Thin section grain size analysis revisited. Sedimentology 41, 985999 (1994). doi:10.1111/j.1365-3091.1994.tb01436.x

31. Coastal Engineering Research Center, Shore Protection Manual (Department of the Army, Waterways Experiment Station, Corps of Engineers, 1984).

32. K. Hasselmann, W. Sell, D. B. Ross, P. Müller, A parametric wave prediction model. $\begin{array}{llll}\text { J. Phys. Oceanogr. 6, 200-228 (1976). doi:10.1175/1520- } & \end{array}$ 0485(1976)006<0200:APWPM>2.0.C0:2

33. M. P. Lamb, W. Fischer, T. D. Raub, J. T. Perron, P. M. Myrow, Origin of giant wave ripples in snowball Earth cap carbonate. Geology 40, 827-830 (2012). doi:10.1130/G33093.1

34. P. W. Schmidt, G. E. Williams, M. O. McWilliams, Palaeomagnetism and magnetic 
anisotropy of late Neoproterozoic strata, South Australia: Implications for the palaeolatitude of late Cryogenian glaciation, cap carbonate and the Ediacaran
System.
Precambrian
Res.
174, $\quad 35-52$
(2009).

doi:10.1016/.jprecamres.2009.06.002

\section{ACKNOWLEDGMENTS}

We thank the reviewers of this manuscript for their helpful and insightful reviews. We thank Catherine Rose, Woody Fischer, and J. C. Creveling for discussions concerning the results of our work. Funding: This study was supported by the U.S. National Science Foundation through award EAR-1225879 to P.M.M and award EAR-PF-0846233 to R.C.E. Author contributions: All authors contributed equally to study concept, data collection and analysis, and manuscript writing. Competing interests: Authors have no competing interests. Data and materials availability: All data are available in the manuscript or the supplementary materials.

\section{SUPPLEMENTARY MATERIALS}

www.sciencemag.org/cgi/content/full/science.aap8612/DC1

Materials and Methods

Figs. S1 to S2

Tables S1 to S3

References (30-34)

3 September 2017; accepted 5 April 2018

Published online 19 April 2018

10.1126/science.aap8612 

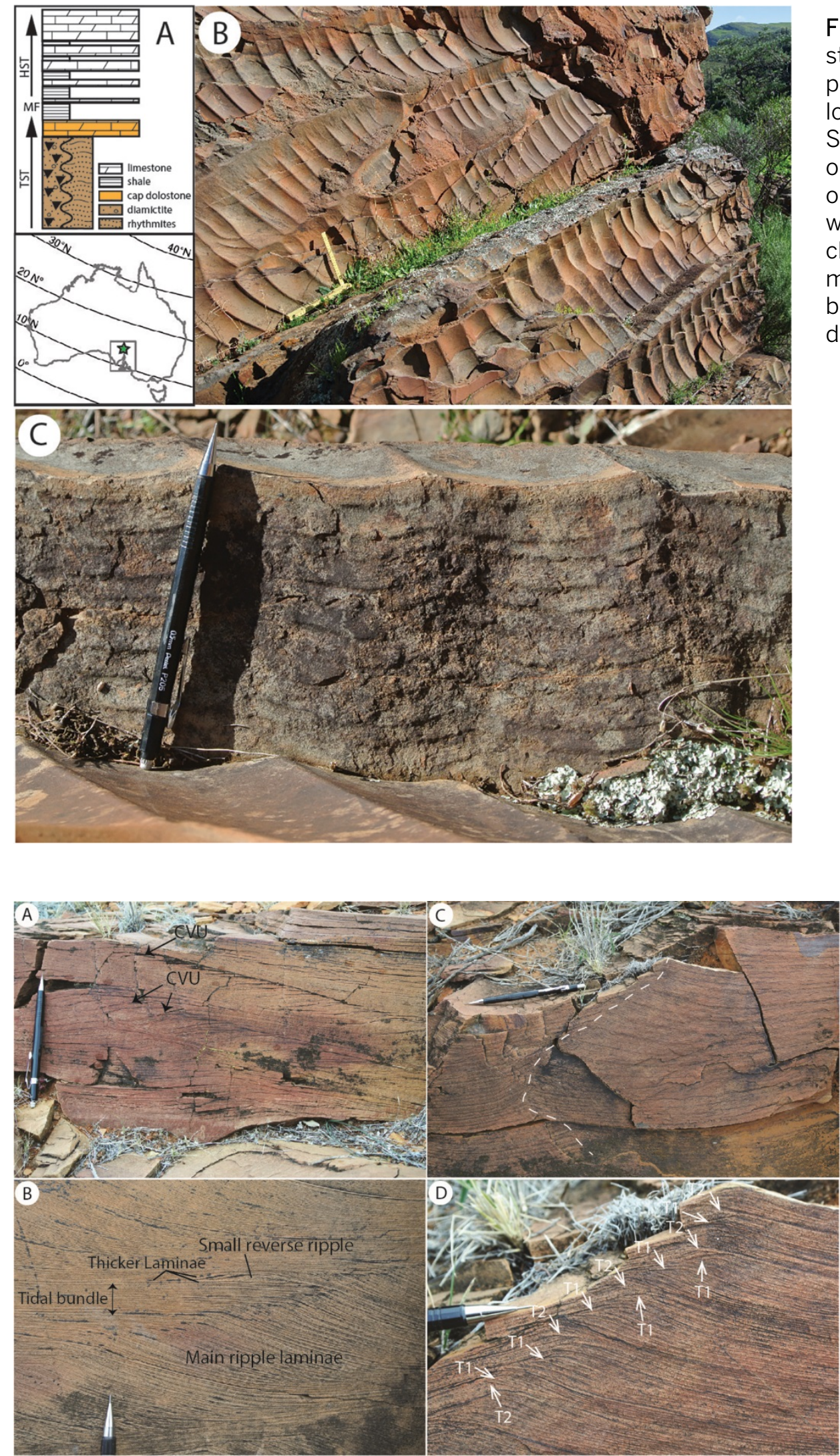

Fig. 1. Elatina Formation. (A) Generalized stratigraphic succession of Marinoan glacial and postglacial deposits modified from (2), and study location (star) with paleolatitude lines (26) in South Australia. (B) Planview (bedding plane) outcrop showing larger first-order ripples oriented perpendicular to second order ripples with locally developed bifurcations. (C) Vertically climbing secondary ripples in cross-section. Note mm-scale tidal laminae. Laminae bundle boundaries highlighted by $\mathrm{cm}$-scale spaced darker laminae. Pencil is $14 \mathrm{~cm}$ long.

Fig. 2. Sedimentary structures of firstorder ripples. (A) Stoss-erosional to nearly stoss-preservational first-order ripple cross-stratification with convex-up (CVU) lamination typical of combined-flow ripples. (B) Migrating ripple lamination with bundled tidal laminae. Note small ripple with cross-stratification that dips opposite to the main ripple laminae. (C) Climbing first-order ripple crossstratification with lower part recording bedform climb to the left, and upper part reversing to the right, similar to cap carbonate strata (27). (D) Close-up of upper part of panel (C). Truncation surfaces that are flat to slightly inclined to the right (T1) become conformable downdip with laminae defining the crosslamination of the ripple. These surfaces truncate laminae on the stoss side of the ripple that are dipping to the left. Surfaces that are moderately inclined to the left (T2) truncate the main cross-lamination of the ripple. The two truncation-surface types generally alternate along the trace of the ripple crest. Pencil is $14 \mathrm{~cm}$ long. 

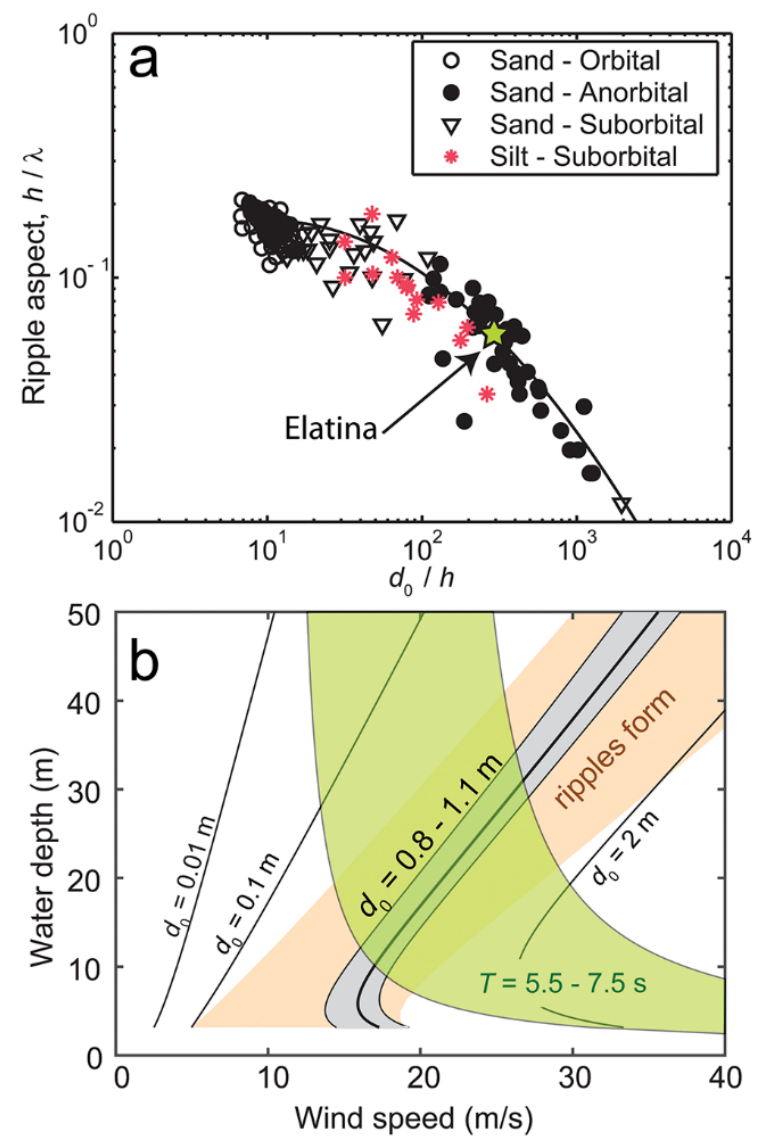

Fig. 3. Paleohydraulic reconstructions. (A) Wave ripple geometry ( $h$ is ripple height, $\lambda$ is ripple crest-to-crest spacing) as a function of normalized orbital diameter, $d_{0}$. Sand-bed field data (28) include orbital, suborbital and anorbital ripples. Silt-bed experiments (16) produced ripples with geometries and grainsizes similar to Elatina ripples. Solid line represents Eq. (1) (11). (B) Combinations of average wind speed and water depth capable of producing $d_{0}=0.95 \pm 0.15 \mathrm{~m}$ (gray shade) according to a wave generation model (11). Orange shaded region marks where wave ripples are stable (29) for 50-micron silt (11), and the green shaded region corresponds to wave periods, $T$, of $5.5-7.5 \mathrm{~s}$, conditions in which ripples similar the Elatina formed in experiments (16). Reconstruction is based on $75 \mathrm{~km}$ fetch inferred from paleogeographic reconstructions (10); varying fetch within a factor of two $(38-150 \mathrm{~km})$ has a negligible effect on the water depth. 